\title{
Beyond the iron age: the ecological relevance of non-ferrous bioactive trace metals and organic growth factors in aquatic systems
}

\author{
Laura Gómez-Consarnau ${ }^{1 *}$ and Sergio A. Sañudo-Wilhelmy ${ }^{1,2 *}$ \\ ${ }^{1}$ Department of Biological Sciences, University of Southern California, Los Angeles, CA, USA, ${ }^{2}$ Department of Earth \\ Sciences, University of Southern California, Los Angeles, CA, USA
}

Keywords: vitamin, bacterioplankton, cofactor, vanadium, molybdenum, nitrogen fixation, cobalamin, thiamin

OPEN ACCESS

Edited by: Jonathan P. Zehr University of California,

Santa Cruz, USA

Reviewed by:

Robert M. McKay,

Bowling Green State University, USA

*Correspondence:

Laura Gómez-Consarnau,

gomezcon@usc.edu;

Sergio A. Sañudo-Wilhelmyt, sanudo@usc.edu

Specialty section: This article was submitted to Aquatic Microbiology, a section of the journal

Frontiers in Microbiology

Received: 08 January 2015 Accepted: 03 March 2015

Published: 20 March 2015

Citation

Gómez-Consarnau $L$ and Sañudo-Wilhelmy SA (2015) Beyond the iron age: the ecological relevance of non-ferrous bioactive trace metals and organic growth factors in aquatic

systems. Front. Microbiol. 6:218. doi: 10.3389/fmicb.2015.00218
The catalysis of chemical reactions is one of the most central processes in biology, as most reactions in living organisms would occur too slowly to play any role in their metabolism. For example, the rate of biologically relevant reactions would take hundreds to millions of years in the absence of a catalyst (Stockbridge et al., 2010). Enzymes are the catalysts of nature, and they can increase the rate of a chemical reaction by as much as $10^{20}$ times compared to an uncatalyzed reaction in water (Lad et al., 2003). Molecular evidence suggests that enzymatic catalysis evolved very early in life history, even prior to the Archaean genetic expansion (David and $\mathrm{Alm}, 2010)$. While some protein functional groups can act as catalysts, they represent a very limited set of reactions as compared to the multitude of enzyme-catalyzed reactions (Price and Stevens, 1999; Bugg, 2012). Enzymes utilize a variety of non-protein molecules or metal ions to increase their versatility in catalytic capacity. Coenzymes and cofactors are the non-protein components of the enzymes that help catalyze the reactions. Coenzymes are typically vitamin B derivatives while cofactors are molecules or metal ions that are covalently bound to the enzyme (Broderick, 2001).

The multiple oxidation states of some metals increase the functionality of the enzymes. Most of the first row transition metals as well as $\mathrm{Mo}, \mathrm{W}$, and $\mathrm{Mg}$ are known to function as cofactors in enzymatic catalysis (da Silva and Williams, 2001). Fe is the most abundant transition element in the Earth's crust and, although it is very scarce in the ocean, this element was very abundant at the onset of life (Anbar, 2008). Therefore, it is not surprising that $\mathrm{Fe}$ is a major cofactor in some of the most central processes in different biological systems (da Silva and Williams, 2001). Starting with the pioneering work of John Martin and collaborators in the early 1990s (Iron limitation?, 2000; Martin et al., 1991), the so-called iron hypothesis has produced major breakthroughs in our understanding of the fundamental role it plays in the marine carbon cycle (Smetacek et al., 2012; Thiele et al., 2012). However, biological activity is not entirely sustained by $\mathrm{Fe}$ alone as other elements are used as cofactors in relevant metabolic reactions such as $\mathrm{Mo}, \mathrm{V}$, and $\mathrm{Ni}$ for $\mathrm{N}$ and $\mathrm{H}_{2}$ activation respectively, and $\mathrm{Cu}$ and $\mathrm{Zn}$ in superoxide dismutase (da Silva and Williams, 2001).

B-vitamins are small organic molecules associated with a large number of biologically important enzymes across all domains of life (Sañudo-Wilhelmy et al., 2014). Decades ago, Carlucci, Droop, Provasoli and others showed that the availability of different B vitamins influenced phytoplankton dynamics in the ocean (Droop, 1957; Carlucci and Silbernagel, 1969; Provasoli and Carlucci, 1974; Swift, 1980). Those initial studies also showed that many marine algae require vitamins $\mathrm{B}_{1}$ (thiamin), $\mathrm{B}_{7}$ (biotin), and $\mathrm{B}_{12}$ (cobalamin) as growth factors (Provasoli and Carlucci, 1974). Those results have recently been validated as field amendments 
of different B-vitamins increase phytoplankton growth in many regions of the ocean (Bertrand and Allen, 2012), suggesting that phytoplankton communities in large areas are indeed limited by the availability of these organic metabolites. The initial notion that B-vitamin auxotrophy (i.e., B-vitamin requirement) only applies to phytoplankton species has been reevaluated as it is now well accepted that some bacterial taxa are also auxotrophic (Giovannoni et al., 2005; Croft et al., 2006; Carini et al., 2014; SañudoWilhelmy et al., 2014). Therefore, both vitamin-producing and -consuming bacteria and algae seem to coexist in the ocean. However, more studies are needed to understand the ecological role of the B-vitamins in the marine environment.

A total of 10 manuscripts are included in this e-book being published in Frontiers in Microbiology; 7 are original research ( 3 on vitamins and 4 on trace metals), 2 reviews and 1 methods article that address some aspect of bioactive trace elements other than $\mathrm{Fe}$, as well as B-vitamins in aquatic environments. The two review articles published focused on the transition element Mo. Glass et al. (2012) reviewed the current state of knowledge regarding Mo limitation in aquatic systems (Glass et al., 2012). One of their major conclusions is that Mo availability seems to influence the $\mathrm{N}$ cycle in some freshwater and soil environments, although the authors also concluded that the impact of this element in open ocean waters have not been thoroughly studied. The mini-review by Wang (2012) seeks to elucidate a connection between the evolution of different Mo-requiring enzymes with historical changes in the redox chemistry of Mo in the ocean (Wang, 2012). Those two reviews are complemented by the work of Romero et al. (2013) showing that, in some lakes with different trophic status, field amendments of a specific chemical form of Mo enhanced nitrogen fixation and biomass concentrations (Romero et al., 2013). The biological role of Mo and its geochemical analog, $\mathrm{V}$, in open ocean waters was evaluated in the article of Klein et al. (2013). They found statistical correlations between intracellular levels of Mo measured in natural phytoplankton communities and dimethyl sulfide (DMS) concentrations as well as between intracellular $\mathrm{V}$ concentrations and chlorophyll a in the North East Atlantic. While the authors stated that the Mo-DMS relationship was not unexpected as the synthesis of DMS is catalyzed by the Mo-containing enzyme dimethyl sulfoxide reductase, they did not put forward an explanation for the biological role of $\mathrm{V}$ in their study. Indeed, $\mathrm{V}$ availability could enhance chlorophyll-a biosynthesis by increasing the synthesis of the chlorophyll-precursor, 5-aminolevulinic acid, via the C5 pathway as has previously been observed (Meisch and Bielig, 1975). However, further studies are needed to test the Vchlorophyll connection. The biological importance of another under-studied transition element, $\mathrm{Ni}$, is explored in the article of Ho et al. (2013) who studied the effect of light intensity and $\mathrm{Ni}$ availability on Trichodesmium growth. The authors concluded that high intracellular levels of $\mathrm{Ni}$ in the diazotroph measured under illumination were probably associated with the activity of the Ni-containing superoxide dismutase enzyme that catalyzes the disproportionation of the superoxide radical formed during photosynthesis. The article by Mackey et al. (2012) explores how the atmospheric deposition of different metals could selectively affect phytoplankton community dynamics in coastal and open ocean waters of the Sargasso Sea. Their work showed that the biological response to the aerosol-derived transition trace metal additions was spatially dependent, as the greater biological drawdown of dissolved $\mathrm{Co}, \mathrm{Mn}$, and $\mathrm{Ni}$ occurred in the open ocean. Therefore, although aerosol metal additions did not cause a shift in the phytoplankton communities, the growth responses were different across ocean regimes. Mackey et al. (2012) hypothesized that the varying biological response was dependent on the metal-nutritional status of the resident phytoplankton prior to the aerosols input, although establishing background metal concentrations prior to addition experiments has faced analytical difficulties due to the complexity of metal analyses at the levels found in open ocean waters. The article of Durand et al. (2012) is a step-forward in the direction to solve that problem. They developed a new microplate-reader method for the rapid analysis of $\mathrm{Cu}$ in natural waters that requires less than 1 milliliter of sample and can process about 100 samples per hour. Although Durand et al. (2012) recognized that the analytical method has to be optimized prior to use in open ocean waters, they provide a series of recommendations that could increase the usefulness of their technique. Three articles published in this ebook concentrated on B-vitamins in different marine environments. The articles of Barada et al. (2013) and Bonnet et al. (2013) established spatial gradients in the Mediterranean Sea and in the Amazon River plume respectively. These two studies significantly increased the geographical database of ambient B-vitamin concentrations in the ocean. As observed in other regions (Sañudo-Wilhelmy et al., 2012), those two studies also showed that large areas in Mediterranean and in the Western Tropical North Atlantic are devoid of vitamins. However, Barada et al. (2013) and Bonnet et al. (2013) found significant correlations between different vitamin levels and chlorophyll a concentrations as well as with $\mathrm{C}$ and $\mathrm{N}$ fixation respectively at some locations, suggesting a potential role of those coenzymes on ecosystem dynamics. The effect of vitamins $B_{1}$ and $B_{12}$ on coastal ecosystem dynamics was the main objective of the article of Koch et al. (2012). The authors established the effect of vitamin additions on the planktonic community composition, carbon fixation, and B-vitamin assimilation in two costal sites off Long Island, New York with different trophic characteristics. The reported results were counterintuitive, as dissolved vitamin concentrations and uptake rates were higher in the most eutrophic environment. Koch et al. (2012) concluded that the major B-vitamin consumers in their study sites were heterotrophic bacteria, consistent with genomic results indicating that some heterotrophs are B-vitamin auxotrophs (SañudoWilhelmy et al., 2014). In summary the articles published in this ebook represent a significant advance in our understanding of the roles that trace metals other than Fe and B-vitamins play in the marine environment. 


\section{References}

Anbar, A. D. (2008). OCEANS: elements and evolution. Science 322, 1481-1483. doi: $10.1126 /$ science. 1163100

Barada, L. P., Cutter, L., Montoya, J. P., Webb, E. A., Capone, D. G., and SañudoWilhelmy, S. A. (2013). The distribution of thiamin and pyridoxine in the western tropical North Atlantic Amazon river plume. Front. Microbiol. 4:25. doi: $10.3389 /$ fmicb.2013.00025

Bertrand, E. M., and Allen, A. E. (2012). Influence of vitamin B auxotrophy on nitrogen metabolism in eukaryotic phytoplankton. Front. Microbiol. 3:375. doi: 10.3389/fmicb.2012.00375

Bonnet, S., Tovar-Sánchez, A., Panzeca, C., Duarte, C. M., Ortega-Retuerta, E., and Sañudo-Wilhelmy, S. A. (2013). Geographical gradients of dissolved Vitamin $\mathrm{B}_{12}$ in the Mediterranean Sea. Front. Microbiol. 4:126. doi: 10.3389/fmicb.2013.00126

Broderick, J. B. (2001). Coenzymes and Cofactors. Chichester: John Wiley \& Sons, Ltd.

Bugg, T. D. H. (2012). Introduction to Enzyme and Coenzyme Chemistry. Chichester, UK: John Wiley \& Sons.

Carini, P., Campbell, E. O., Morré, J., Sañudo-Wilhelmy, S. A., Cameron Thrash, J., Bennett, S. E., et al. (2014). Discovery of a SAR11 growth requirement for thiamin's pyrimidine precursor and its distribution in the Sargasso Sea. ISME J. 8, 1727-1738. doi: 10.1038/ismej.2014.61

Carlucci, A. F., and Silbernagel, S. B. (1969). Effect of vitamin concentrations on growth and development of vitamin-requiring algae. J. Phycol. 5, 64-67. doi: 10.1111/j.1529-8817.1969.tb02578.x

Croft, M. T., Warren, M. J., and Smith, A. G. (2006). Algae need their vitamins. Eukaryot. Cell 5, 1175-1183. doi: 10.1128/EC.00097-06

da Silva, J. J. R. F., and Williams, R. J. P. (2001). The Biological Chemistry of the Elements. New York, NY: Oxford University Press.

David, L. A., and Alm, E. J. (2010). Rapid evolutionary innovation during an Archaean genetic expansion. Nature 469, 93-96. doi: 10.1038/nature 09649

Droop, M. R. (1957). Vitamin-B 12 in marine ecology. Nature 180, 1041-1042. doi: 10.1038/1801041b0

Durand, A., Chase, Z., Remenyi, T., and Quéroué, F. (2012). Microplate-reader method for the rapid analysis of copper in natural waters with chemiluminescence detection. Front. Microbiol. 3:437. doi: 10.3389/fmicb.2012.00437

Giovannoni, S. J., Tripp, H. J., Givan, S., Podar, M., Vergin, K. L., Baptista, D., et al. (2005). Genome streamlining in a cosmopolitan oceanic bacterium. Science 309, 1242-1245. doi: 10.1126/science. 1114057

Glass, J. B., Axler, R. P., Chandra, S., and Goldman, C. R. (2012). Molybdenum limitation of microbial nitrogen assimilation in aquatic ecosystems and pure cultures. Front. Microbiol. 3:331. doi: 10.3389/fmicb.2012.00331

Ho, T.-Y., Chu, T.-H., and Hu, C.-L. (2013). Interrelated influence of light and $\mathrm{Ni}$ on Trichodesmium growth. Front. Microbiol. 4:139. doi: 10.3389/fmicb.2013.00139

Klein, N. J., Beck, A. J., Hutchins, D. A., and Sañudo-Wilhelmy, S. A. (2013). Regression modeling of the North East Atlantic spring bloom suggests previously unrecognized biological roles for V and Mo. Front. Microbiol. 4:45. doi: 10.3389/fmicb.2013.00045

Koch, F., Hattenrath-Lehmann, T. K., Goleski, J. A., Sañudo-Wilhelmy, S., Fisher, N. S., and Gobler, C. J. (2012). Vitamin $B_{1}$ and $B_{12}$ uptake and cycling by plankton communities in coastal ecosystems. Front. Microbiol. 3:363. doi: 10.3389/fmicb. 2012.00363
Lad, C., Williams, N. H., and Wolfenden, R. (2003). The rate of hydrolysis of phosphomonoester dianions and the exceptional catalytic proficiencies of protein and inositol phosphatases. Proc. Natl. Acad. Sci. U.S.A. 100, 5607-5610. doi: 10.1073/pnas.0631607100

Mackey, K. R. M., Buck, K. N., Casey, J. R., Cid, A., Lomas, M. W., Sohrin, Y., et al. (2012). Phytoplankton responses to atmospheric metal deposition in the coastal and open-ocean Sargasso Sea. Front. Microbiol. 3:359. doi: 10.3389/fmicb.2012.00359

Martin, J. H., Gordon, R. M., and Fitzwater, S. E. (1991). Iron limitation? The case for iron. Limnol. Oceanogr. 30, 1793-1802. doi: 10.4319/lo.1991.36.8.1793

Meisch, H. U., and Bielig, H. J. (1975). Effect of vanadium on growth, chlorophyll formation and iron metabolism in unicellular green algae. Arch. Microbiol. 105, 77-82. doi: 10.1007/BF00447117

Price, N. C. A., and Stevens, L. A. (1999). Fundamentals of Enzymology. New York, NY: Oxford University Press.

Provasoli, L., and Carlucci, A. F. (1974). "Vitamins and growth regulators," in Algal Physiology and Chemistry, ed W. D. P. Stewart (Berkeley: University of California Press), 741-787.

Romero, I. C., Klein, N. J., Sañudo-Wilhelmy, S. A., and Capone, D. G. (2013). Potential trace metal co-limitation controls on $\mathrm{N}_{2}$ fixation and uptake in lakes with varying trophic status. Front. Microbiol. 4:54. doi: 10.3389/fmicb.2013.00054

Sañudo-Wilhelmy, S. A., Cutter, L. S., Durazo, R., Smail, E. A., Gómez-Consarnau, L., Webb, E. A., et al. (2012). Multiple B-vitamin depletion in large areas of the coastal ocean. Proc. Natl. Acad. Sci. U.S.A. 109, 14041-14045. doi: 10.1073/pnas.1208755109

Sañudo-Wilhelmy, S. A., Gómez-Consarnau, L., Suffridge, C., and Webb, E. A. (2014). The role of B vitamins in marine biogeochemistry. Annu. Rev. Marine Sci. 6, 339-367. doi: 10.1146/annurev-marine-120710-100912

Smetacek, V., Klaas, C., Strass, V. H., Assmy, P., Montresor, M., Cisewski, B., et al. (2012). Deep carbon export from a Southern Ocean iron-fertilized diatom bloom. Nature 487, 313-319. doi: 10.1038/nature11229

Stockbridge, R. B., Lewis, C. A., Yuan, Y., and Wolfenden, R. (2010). Impact of temperature on the time required for the establishment of primordial biochemistry, and for the evolution of enzymes. Proc. Natl. Acad. Sci. U.S.A. 107, 22102-22105. doi: 10.1073/pnas.1013647107

Swift, D. G. (1980). "Vitamins and phytoplankton growth," in The Physiological Ecology of Phytoplankton, ed I. Morris (Oxford: Blackwell), 329-369.

Thiele, S., Fuchs, B. M., Ramaiah, N., and Amann, R. (2012). Microbial community response during the Iron Fertilization Experiment LOHAFEX. Appl. Environ Microbiol. 78, 8803-8812. doi: 10.1128/AEM.01814-12

Wang, D. (2012). Redox chemistry of molybdenum in natural waters and its involvement in biological evolution. Front. Microbiol. 3:427. doi: $10.3389 /$ fmicb. 2012.00427

Conflict of Interest Statement: The authors declare that the research was conducted in the absence of any commercial or financial relationships that could be construed as a potential conflict of interest.

Copyright (C) 2015 Gómez-Consarnau and Sañudo-Wilhelmy. This is an open-access article distributed under the terms of the Creative Commons Attribution License (CC $B Y)$. The use, distribution or reproduction in other forums is permitted, provided the original author(s) or licensor are credited and that the original publication in this journal is cited, in accordance with accepted academic practice. No use, distribution or reproduction is permitted which does not comply with these terms. 